\title{
Virus-Specific Read-Through Codon Preference Affects Infectivity of Chimeric Cucumber Green Mottle Mosaic Viruses Displaying a Dengue Virus Epitope
}

\author{
Pak-Guan Teoh, ${ }^{1}$ Aik-Seng Ooi, ${ }^{1}$ Sazaly AbuBakar, ${ }^{2}$ and Rofina Yasmin Othman' \\ ${ }^{1}$ Center for Research in Biotechnology for Agriculture (CEBAR) and Institute of Biological Sciences, Faculty of Science, \\ University of Malaya, Kuala Lumpur 50603, Malaysia \\ ${ }^{2}$ Department of Medical Microbiology, Faculty of Medicine, University of Malaya, Kuala Lumpur 50603, Malaysia
}

Correspondence should be addressed to Rofina Yasmin Othman, yasmin@um.edu.my

Received 12 August 2008; Accepted 7 January 2009

Recommended by George E. Plopper

\begin{abstract}
A Cucumber green mottle mosaic virus (CGMMV) was used to present a truncated dengue virus type 2 envelope (E) protein binding region from amino acids 379 to 423 (EB4). The EB4 gene was inserted at the terminal end of the CGMMV coat protein (CP) open reading frame (ORF). Read-through sequences of TMV or CGMMV, CAA-UAG-CAA-UUA, or AAA-UAG-CAA-UUA were, respectively, inserted in between the CP and the EB4 genes. The chimeric clones, pRT, pRG, and pCG+FSRTRE, were transcribed into full-length capped recombinant CGMMV transcripts. Only constructs with the wild-type CGMMV read-through sequence yielded infectious viruses following infection of host plant, muskmelon (Cucumis melo) leaves. The ratio of modified to unmodified $\mathrm{CP}$ for the read-through expression clone developed was also found to be approximately 1:1, higher than what has been previously reported. It was also observed that infectivity was not affected by differences in pI between the chimera and its wild counterpart. Analysis of recombinant viruses after 21-days-postinculation (dpi) revealed that deletions occurred resulting in partial reversions of the viral population to near wild type and suggesting that this would be the limiting harvest period for obtaining true to type recombinants with this construct.
\end{abstract}

Copyright (C) 2009 Pak-Guan Teoh et al. This is an open access article distributed under the Creative Commons Attribution License, which permits unrestricted use, distribution, and reproduction in any medium, provided the original work is properly cited.

\section{Introduction}

The development of plant virus vectors as in planta expression systems for foreign genes provides an attractive alternative biotechnological approach for peptide expression [15]. This method has been exploited in vaccine production, where small foreign peptides are expressed as a fusion with the viral coat proteins. Essentially, an insertion site has to be determined in the virus genome so that the resulting product will be displayed on the surface of the virus particle which is then propagated in plants and consequently isolated and used as antigen presenting vehicles $[5,6]$. Modifications that do not interfere with the normal functions of the particular virus are a prerequisite for this peptide fusion approach. One strategy suggests that foreign gene segments could be fused to the terminus of a viral gene in a way that permits the production of both the fusion product and the native viral protein, thus avoiding interference with normal gene functions. The success of this epitope presentation strategy depends on a detailed knowledge of virus structure at the atomic level, which is only available for a limited number of viruses.

We have recently developed Cucumber green mottle mosaic virus (CGMMV) as a candidate for expressing antigenic peptides in plants [7]. CGMMV is a tobamovirus with a genome size of $\sim 6.4 \mathrm{~kb}$ which has been well characterized both biologically $[8,9]$ and structurally $[10,11]$. In this study, a truncated dengue virus type 2 envelope (E) protein binding region from amino acid 379 to 423 (EB4) was inserted into the end of the coat protein $(\mathrm{CP})$ open reading frame (ORF) of a previously constructed CGMMV fulllength clone, pCGT7X [7]. The antigenic peptide was chosen based on a recent study that suggests its importance in enabling dengue virus to bind to specific host cell receptors (S. Abu Bakar personal communication). The present study explores the possibility of extrapolating the CGMMV antigenic epitope presentation system for developing diagnostics 


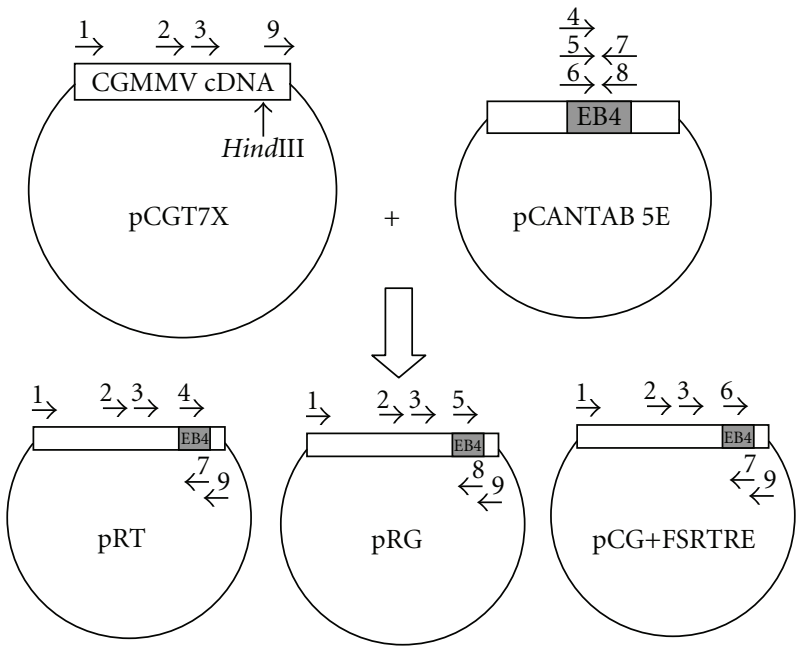
Primer names
1. CGT7doubleG
2. Pst I sense
3. $\mathrm{C} 5500 \mathrm{~F}$
4. Forward RT

\begin{abstract}
5. Forward (RT)TGG
6. Forward SRT

7. Reverse $\mathrm{E}$

8. Reverse Q

9. CGMMV 3'UTR
\end{abstract}

Figure 1: Position of primers in constructed plasmid clones. Primers $4-8$ were used to amplify the EB4 gene from pCANTAB 5E. Plasmid pCGT7X and amplified EB4 fragments were digested with HindIII and ligated together to obtain the respective plasmid clones as shown. HindIII is the insertion site of EB4 at the end of CGMMV CP. PCR amplification using primer pairs 1-9, 3-9, and 2-7 will yield amplified products of approximately $6.5 \mathrm{~kb}, 0.85 \mathrm{~kb}$, and $2.2 \mathrm{~kb}$, respectively.

and potentially therapeutics against dengue. The study was also used to challenge the size limits of foreign gene insertion into the CGMMV vector as in the previous study the hepatitis B surface antigen (HBsAg) used was only 33 amino acids [7].

\section{Materials and Methods}

2.1. The Antigenic Epitope. The 45 amino acid-long EB4 protein used in this study has been previously shown to react with the dengue-specific antibody 3H5-1 (S. Abu Bakar personal communication).

2.2. Construction of Chimeric CGMMV Vector. The EB4 coding sequence was amplified from a pCANTAB $5 \mathrm{E}$ vector carrying the virus gene using 3 primer pair sets. The resulting PCR products were purified then digested overnight with HindIII restriction endonuclease, with the same treatment carried out on the full-length clone of CGMMV (pCGT7X, $\sim 9.0 \mathrm{~kb}$ ) previously constructed [7]. The digested PCR products and the linearized PCGT7X were purified following $1 \%$ agarose gel electrophoresis, and then ligated to form pRT, pRG, both containing the TMV read-through sequence [12] and PCG+FSRTRE (containing the CGMMV read-through sequence) [13], respectively (Figure 1). The three primer sets used in the amplifications were as follows.
Forward RT (5'-CCAAGCTTGCCAATAGCAATTAATCATAGGAGTAGAGC- $3^{\prime}$ ) and Reverse E (5'-CCAAGCTTCTCCAAAATCCCAAGCTGT- $3^{\prime}$ ) for construction of clone pRT, Forward (RT) TGG (5' -AAGCTTGGCAATAGCAATTAATCATAGGAGTAGAGCCG- $\left.3^{\prime}\right)$ and Reverse Q ( $5^{\prime}$ CCAAGCTTGTCCAAAATCCCAAGCTGTGT-3') for clone pRG, and Forward SRT (5'-CCAAGCTTCCAAATAGCAATTAATCATAGGAGTAGAGCCG-3') and Reverse E (5'CCAAGCTTCTCCAAAATCCCAAGCTGT-3') for clone pCG+FSRTRE.

2.3. Production of Infectious RNA. The templates used in the in vitro transcription reactions were synthesized through long-distance PCR (LD-PCR) in $50 \mu \mathrm{L}$ PCR cocktails containing 1X HF Buffer of Phusion DNA Polymerase (Finnzymes, Espoo, Finland) with $1.5 \mathrm{mM} \mathrm{MgCl}_{2}$ (Finnzymes, Espoo, Finland), $0.2 \mathrm{mM}$ dNTP mix, $0.5 \mu \mathrm{M}$ forward primer, CGT7dG (5'-CCGAGCTCGTAATACGACTCACTATAGGTTTTA- $\left.3^{\prime}\right), 0.5 \mu \mathrm{M}$ reverse primer, CGMMV $3^{\prime}$-UTR ( $5^{\prime}$-TGGGCCCCTACCCGGGGAAAAGGGGGGAT-3'), 10-20 ng of DNA template, and $1 \mathrm{U}$ of Phusion DNA Polymerase (Finnzymes, Espoo, Finland). The reaction was set up in $0.2 \mathrm{~mL}$ tubes, and the thermal cycling was conducted with initial denaturation at $98^{\circ} \mathrm{C}$ for 60 seconds, followed by 30 cycles of $98^{\circ} \mathrm{C}$ denaturation for 10 seconds, annealing at $63^{\circ} \mathrm{C}$ for 20 seconds and elongation at $72^{\circ} \mathrm{C}$ for 1 minute and 50 seconds, and finally an extension step at $72^{\circ} \mathrm{C}$ for 5 minutes. The amplified product was purified through phenol-chloroform extraction followed by ethanol precipitation. The pellet was dissolved in an appropriate volume of RNase-free distilled water to $1 \mu \mathrm{g} / \mu \mathrm{L}$ and stored at $-20^{\circ} \mathrm{C}$ till further use. The in vitro transcription was carried out using the (Ambion, Calif, USA) High Yield Capped T7 RNA Transcription Kit according to the manufacturer protocol. Aliquots of the in vitrosynthesized transcripts were denatured and electrophoresed alongside RNA markers showing its integrity and the expected transcript size of approximately $6.5 \mathrm{~kb}$. Since no DNase I treatment was done, traces of DNA template of the transcription reactions were detected.

2.4. Maintaining the Host Plants. Muskmelon (C. melo) plants were used as host plants for virus propagation. Plants used in this study were maintained in a growth room at $25^{\circ} \mathrm{C}$ with 16 hours of light and 8 hours of darkness. Healthy $10-$ day-old plantlets with cotyledons and small first leaf were used for inoculation.

2.5. Inoculation with RNA Transcripts. One transcription reaction was used to inoculate 2 plantlets by gently rubbing the reaction mixture over carborundum-dusted first leaf and cotyledons of 10-day-old plantlets. Mock inoculation was done by gently rubbing distilled water onto carborundumdusted first leaves. The excess inoculum was rinsed off using distilled water from the leaf surfaces 60 minutes after inoculation.

2.6. RT-PCR Detection of Chimeric Virus Infection. Total RNA was isolated from the new leaf of the inoculated and 
healthy plants using RNeasy Plant Mini Kit (QIAGEN). RT-PCR was performed using AccuPower RT/PCR PreMix (Bioneer, Daejeon, South Korea) with primers CGMMV 3'UTR (5'-TGGGCCCCTACCCGGGGAAAAGGGGGGAT- $\left.3^{\prime}\right)$ paired with $P s t$ I sense (5'-TAGGAAAAAACCAGAAGATCTGCAGGAATTTTTCTC-3') or C5500F (5'GTCGCTACAACTAACTCTATTATCAAAAAGGGTC-3'). Reactions were carried out according to the manufacturer protocols. Infected plants will give a PCR-amplified product of approximately $2.2 \mathrm{~kb}$ (with Pst I sense and CGMMV $3^{\prime}$ UTR primers) or $0.85 \mathrm{~kb}$ (with C5500F and CGMMV $3^{\prime}$ UTR primers). RT-PCR reactions were carried out for plants at 14, 21, and 30 day-postinoculation (dpi).

2.7. Virus Purification. Plant virus isolation procedures used in this study were modified from [8]. Infected plants showing typical symptoms were harvested, weighed, and homogenized in ice-cold $0.1 \mathrm{M}$ phosphate buffer $(\mathrm{pH} 7.0$ containing $1 \%$ of $\beta$-mercaptoethanol) at $1 \mathrm{~mL} / \mathrm{g}$ of plant material for 10 minutes using a mechanical blender. The homogenate was filtered through 2 layers of cheesecloth and then mixed with equal volume of chloroform:butanol (1:1). The mixture was then stirred for 1-2 hours at room temperature and then the organic phase was separated from the mixture through centrifugation at $8000 \mathrm{~g}$ for 15 minutes. The aqueous layer was transferred to a beaker, $100 \mathrm{~mL}$ of $\mathrm{NaCl}(4 \mathrm{~g} / \mathrm{L})$ and PEG6000 added, and the mixture stirred on ice for 1 hour. The precipitated virus was separated from the solution through centrifugation at $10000 \mathrm{~g}$ for 30 minutes at $4{ }^{\circ} \mathrm{C}$. The resulting pellet was reconstituted in $10 \mathrm{~mL}$ of $0.1 \mathrm{M}$ phosphate buffer $\mathrm{pH}$ 7.0. Any undissolved material was cleared by centrifugation at $10000 \mathrm{~g}$ for 30 minutes at $12^{\circ} \mathrm{C}$. Then $0.2 \mathrm{M}$ EDTA $(\mathrm{pH} 7)(50 \mathrm{~mL} / \mathrm{L})$ was added to the supernatant and the mixture subjected to centrifugation at $110000 \mathrm{~g}$ for 90 minutes at $4^{\circ} \mathrm{C}$. The supernatant was discarded, and the pellet was left to air dry. The virus pellet was then reconstituted in $100 \mu \mathrm{L}$ of distilled water and stored at $4^{\circ} \mathrm{C}$ until used.

2.8. Analyses of Viral Genome. Analyses of sequences of the amplified products were carried using BioEdit Sequence Alignment Editor Software (version 6.0.5) (http://www.mbio .ncsu.edu/BioEdit/bioedit.html). The pI and charge values of the coat protein were calculated using the protein calculator developed by Chris Putnam of The Scripps Research Institute (http://www. scripps.edu/ cdputnam/protcalc.html).

\section{Results}

3.1. Infectivity of Constructed Transcription Clones-ReadThrough Sequence Preference. In this study, the chimeric CGMMV vectors pRT, pRG, and pCG-FSRTRE were constructed by inserting the EB4 coding sequence to the end of the CGMMV CP ORF in plasmid pCGT7X. The maps of these constructed clones are shown in Figure 1, which indicates their respective position of the primers during amplification and cloning procedures. Maps of plasmids pCGT7X are carrying the wild-type CGMMV, and pCANTAB 5E are

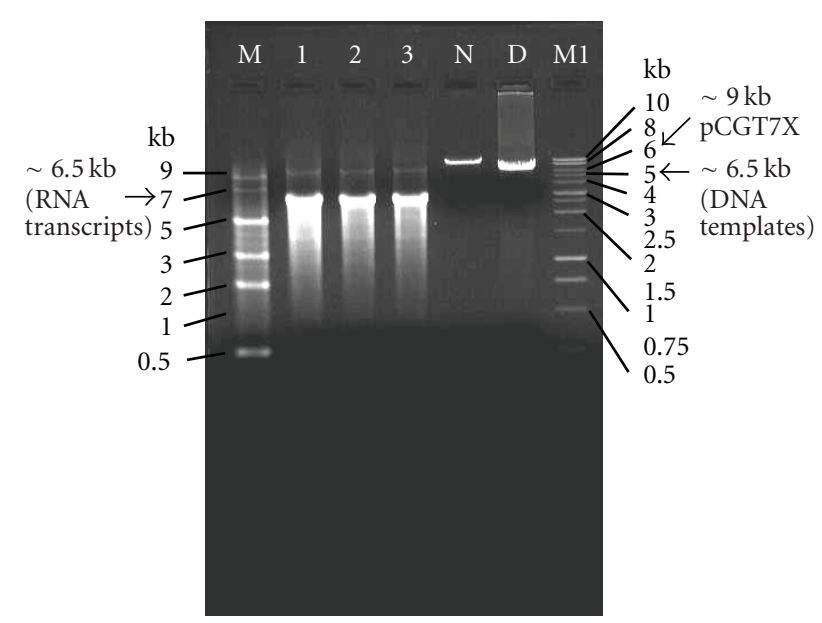

Figure 2: A representative gel image of pCG+FSRTRE-derived transcripts without DNase I treatment electrophoresed after denaturation showing the expected transcript size $(6.5 \mathrm{~kb})$. The band above the transcript band is the DNA template. Lane M: RNA marker (Invitrogen, Calif, USA); 1, 2, 3: produced transcripts; M1: $1 \mathrm{~kb}$ DNA ladder (Promega, Wis, USA); N: pCGT7X, $\sim 9.0 \mathrm{~kb}$; D: DNA template, $\sim 6.5 \mathrm{~kb}$. There were traces of DNA template detected in transcripts without DNase I treatment.

carrying EB4 with their respective priming sites are also as indicated in Figure 1. The genome size of wild-type CGMMV is approximately $6.4 \mathrm{~kb}$ (without the plasmid backbone), and the resulting chimeric CGMMV genome would be approximately $6.5 \mathrm{~kb}$ in size and contains the EB4 and readthrough sequences as well as inserted HindIII restriction recognition sites and additional nucleotides enabling inframe cloning. The pRT and pRG chimeric clones were constructed with the read-through sequence of TMV (CAAUAG-CAA-UUA). This leaky sequence meets the minimal sequence requirement for effective read-through of the stop codon [12] and had been used successfully in previous reports [14].

The templates for in vitro transcription of these two clones were generated through LD-PCR (data not shown). The resulting amplified products $(\sim 6.5 \mathrm{~kb})$ consisted of a T7 promoter fused with the chimeric CGMMV genome carrying EB4. Transcripts produced from the two constructs were separately tested for infectivity by inoculating the host plants. After repeated attempts, both the pRT- and pRG-generated transcripts did not cause infection of the inoculated plants (Table 1). There was no evidence of virus genomic material in the inoculated plant tissues tested (data not shown). It is speculated that the read-through sequence of TMV may not be suitable for the CGMMV chimeric clones, hence contributing to the absence of infectious virus transcripts. To overcome this possibility, another chimeric clone (pCG+FSRTRE) was constructed using the read-through sequence AAA-UAG-CAA-UUA of the wild-type CGMMV itself (Figure 1). The template for in vitro transcription, based on the pCG+FSRTRE clone, was generated through LD-PCR. The in vitro transcription products (Figure 2) were used in inoculation studies. The new leaves of plants 


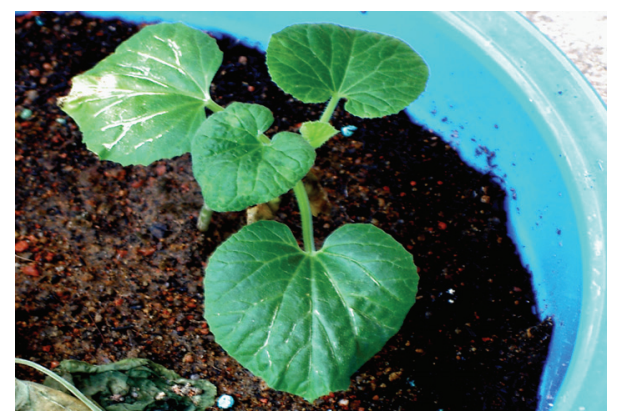

Figure 3: Symptom appearance at 14 day-postinoculation (dpi) on muskmelon plants caused by pCG+FSRTRE-derived transcripts.

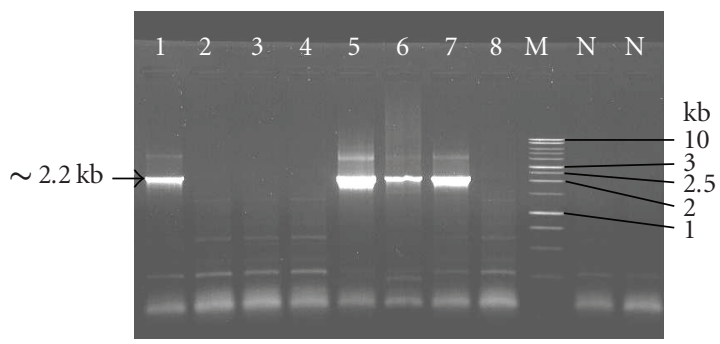

FIGURE 4: Gel image showing presence of amplified band $(\sim 2.2 \mathrm{~kb})$ after RT-PCR using PstI sense and reverse E primer. Lane M: $1 \mathrm{~kb}$ DNA ladder (Promega, Wis, USA); 1-8: total RNA extracted from new noninoculated leaves of pCG+FSRTRE-derived transcripts from infected plants; $\mathrm{N}$ : total RNA of new noninoculated leaves of wild-type transcript from infected plants (negative control).

inoculated with pCG+FSRTRE-derived transcripts showed evidence of virus infection with four out of eight plants showing a typical symptom of CGMMV infection, which include the green mottle mosaic appearance on day $14 \mathrm{pI}$ (Table 1 and Figure 3). Infection could be detected through RT-PCR when total RNA of new noninoculated leaf was used as template. Detection of the virus by RT-PCR (Figure 4) suggests that the viruses had moved from the inoculated leaf to new leaves. This implies that the chimeric virus pCG+FSRTRE carrying the read-through sequence from the CGMMV genome (AAA-UAG-CAA-UUA) was infectious and that the virus particles were able to assemble. The plants, however, continued to grow without any further noticeable symptoms. Virus particles were extracted from the infected plants and an aliquot was electrophoretically separated on 15\% SDS-PAGE (Figure 5) resulting in two distinct suggesting that the virus population consisted of two species of coat proteins, the EB4-CP fusion (larger in size) and the wild-type CGMMV CP (smaller in size). The ratio of modified to unmodified CP was approximately 1:1.

3.2. Effect of pI:Charge Value on Stability of Construct. Apart from the usage of leaky UAG amber stop codons, it has been reported that pI:charge can affect the production of viable recombinant virus [15]. The $\mathrm{pI}$ of the epitope is thought to be an important factor as the hybrid coat protein pI:charge value can affect epitope presentation. It was also reported

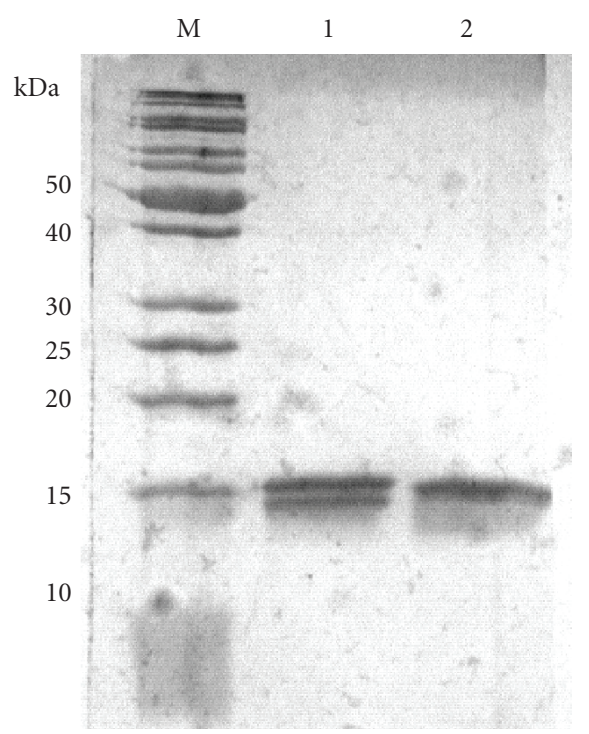

FIGURE 5: SDS-PAGE of purified chimeric virus coat protein (CP). Lane M: protein marker (Fermantas); 1: chimeric virus; 2 : wild-type CGMMV. It is clearly shown that the chimeric virus consisted of two different CP species. The higher molecular band shows the EB4fusion CGMMV coat protein. The ratio of modified to unmodified $\mathrm{CP}$ was approximately $1: 1$.

Table 1: Summary of experiments carried out to assess the infectivity of different transcript clones. ( ${ }^{*}$ Total RNA was extracted from new noninoculated leaves (third new leaf) of transcript infected plants.)

\begin{tabular}{|c|c|c|c|}
\hline $\begin{array}{l}\text { Transcript } \\
\text { clones }\end{array}$ & $\begin{array}{l}\text { Infectivity on } \\
\text { inoculated } \\
\text { plants }\end{array}$ & $\begin{array}{l}\text { Symptom } \\
\text { appearance }\end{array}$ & $\begin{array}{l}* \text { Virus detected } \\
\text { through RT-PCR }\end{array}$ \\
\hline $\mathrm{pRT}$ & $0 / 6$ & Healthy & No \\
\hline $\mathrm{pRG}$ & $0 / 6$ & Healthy & No \\
\hline pCG+FSRTRE & $4 / 8$ & $\begin{array}{l}\text { Green mottle } \\
\text { mosaic }\end{array}$ & Yes \\
\hline
\end{tabular}

that TMV was more tolerant to positively charged epitopes on its surface. Thus, it was initially speculated that the failure in expression of the foreign peptide was possibly due to the pI:charge value of recombinant CGMMV CP which was different from the wild-type CGMMV CP pI:charge value (Table 2).

Table 2 shows the isoelectric point (pI) and charge of the wild-type CGMMV CP, the read-through recombinant CGMMV CP, and the EB4 insert. The charge of the EB4 insert is positive and potentially suitable for expression on the surface of the CGMMV CP [2]. Hence, the inserted peptide is speculated to be expressed if the pI:charge value of modified virus $\mathrm{CP}$ resembles the pI:charge value of unmodified virus CP. Earlier transcripts (data not shown) generated from fusion clones without a read-through sequence, where their pI values deviated significantly (>6.0) from the wildtype CP (5.08), were not able to cause infection in inoculated plants leading to the suggestion initially that pI:charge value 


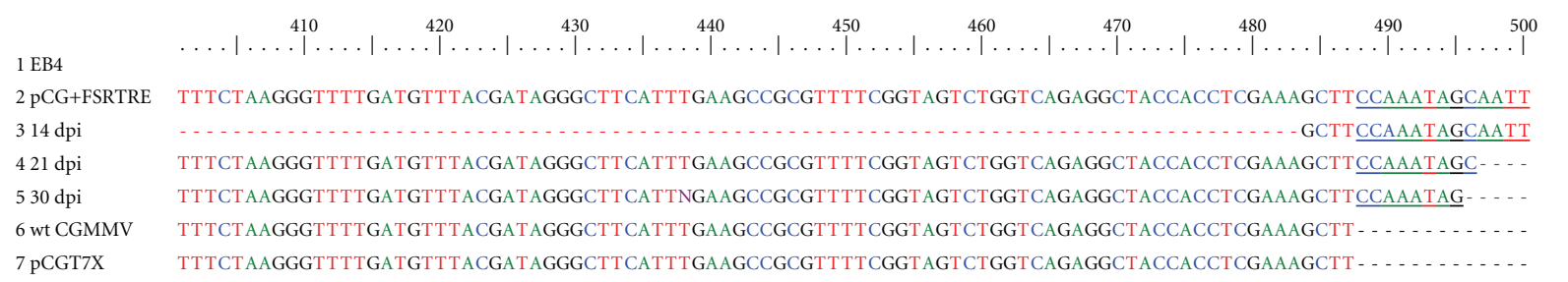

1 EB4
2 pCG+FSRTRE
$314 \mathrm{dpi}$
$421 \mathrm{dpi}$
$530 \mathrm{dpi}$
6 wt CGMMV
7 pCGT7X

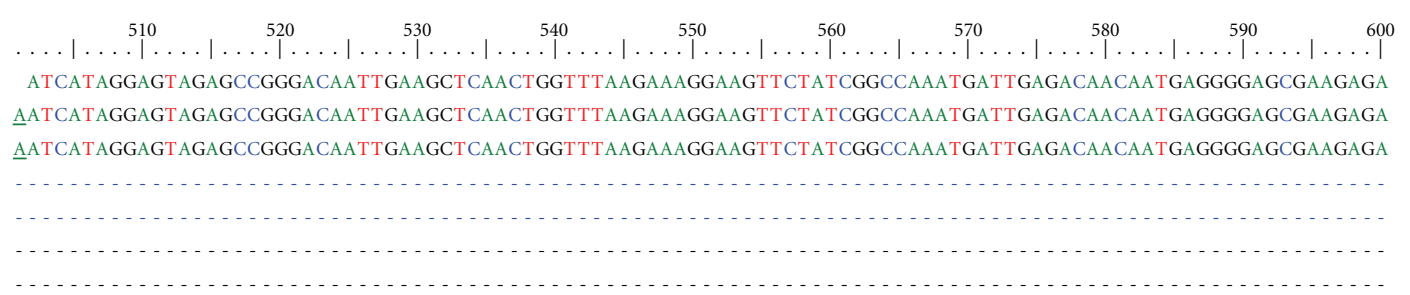

1 EB4
2 pCG+FSRTRE
314 dpi
421 dpi
530 dpi
6 wt CGMMV
7 pCGT7X

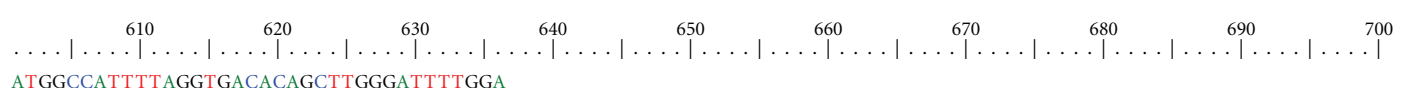

FIGURE 6: Sequence analyses of RT-PCR-amplified products from putative chimeric CGMMV RNA at different days postinoculation (dpi). The sequenced alignment shows that EB4 sequence was truncated and not complete after 21 dpi. The putative chimeric CGMMV produced did not express the EB4 and its genome resembled the wild-type CGMMV. Introduced read-through sequences and extra codons are underlined. Complete EB4 sequence is aligned accordingly with the other sequences.

played an important role in virus particle assembly and infectivity. Thus, the pI value of the recombinant CP constructs was adjusted to more closely resemble the wild-type CP pI value by inserting the acidic amino acid (glutamate) to the $3^{\prime}$ end of CP (Table 2). The experiments (Table 1), however, showed that although the pI was still higher than that of the wild type (Table 2), the construct pCG+FSRTRE remained infectious. This implies that infectivity of the clones was not directly related to the deviation in $\mathrm{pI}$ value with the wild-type virus CGMMV CP.

3.3. Deletion of Cloned Peptide Sequence. Sequencing was carried out on RT-PCR-amplified products of viral RNA extracted from putative chimeric virus particles at 30 days postinoculation (dpi) and total plant RNA isolated from inoculated plant materials at 14 and $21 \mathrm{dpi}$ to confirm the expression of EB4. Sequence analysis was done using BioEdit Sequence Alignment Editor Software (version 6.0.5) (http://www.mbio.ncsu.edu/BioEdit/bioedit.html). The chimeric CP carried the complete EB4 sequence within its genome at $14 \mathrm{dpi}$ (Figure 6). However, the EB4 sequence appeared to be truncated at $21 \mathrm{dpi}$ with an upstream portion of the EB4 sequence was not present. Only part of the downstream sequence of EB4 was detected together with the $3^{\prime}$ untranslated region of the CGMMV. EB4 was totally undetectable at $30 \mathrm{dpi}$. Interestingly, the $5^{\prime}$ end of introduced read-through sequence (position 490 to 501) was retained in the genome. The introduced HindIII recognition site at EB4 downstream from position 639 to 644 was found to have been deleted after $30 \mathrm{dpi}$.

Even though only a single band was visible on RT-PCR screening, it was suspected that there could be products with similar sizes which could not be separated in normal agarose gel electrophoresis, therefore, the RT-PCR products from the chimeric CGMMV RNA at 30 dpi were cloned into pGEM$T$ Easy vector and subjected to sequence analyses. The results (Figure 7) confirmed the absence of the EB4 sequence, except for clone pR_P3U4 (from nucleotide position of 702 to 746), where only part of the downstream sequence of the EB4 was detected together with the $3^{\prime}$ untranslated region of the CGMMV. The $5^{\prime}$ end of introduced read-through sequence of AAA-TAG-CAA-TTA (position 594 to 605) was retained within the genome for all sequenced clones (Figure 7). The introduced HindIII site from position 742 to 747 was deleted for clones pR_P3U1, pR_P3U3, and pR_P3U11 after 30 dpi.

The chimeric CGMMV sequence analyses showed one common similarity (Figures 6 and 7), that is, that part of the read-through amber stops codon sequence, and additional nucleotides "CC-AAA-TAG" were retained for all sequenced clones. This suggests that deletion had occurred within the host plant. The sequence analysis also showed that the EB4 was not fully expressed in the putative chimeric CGMMV. 


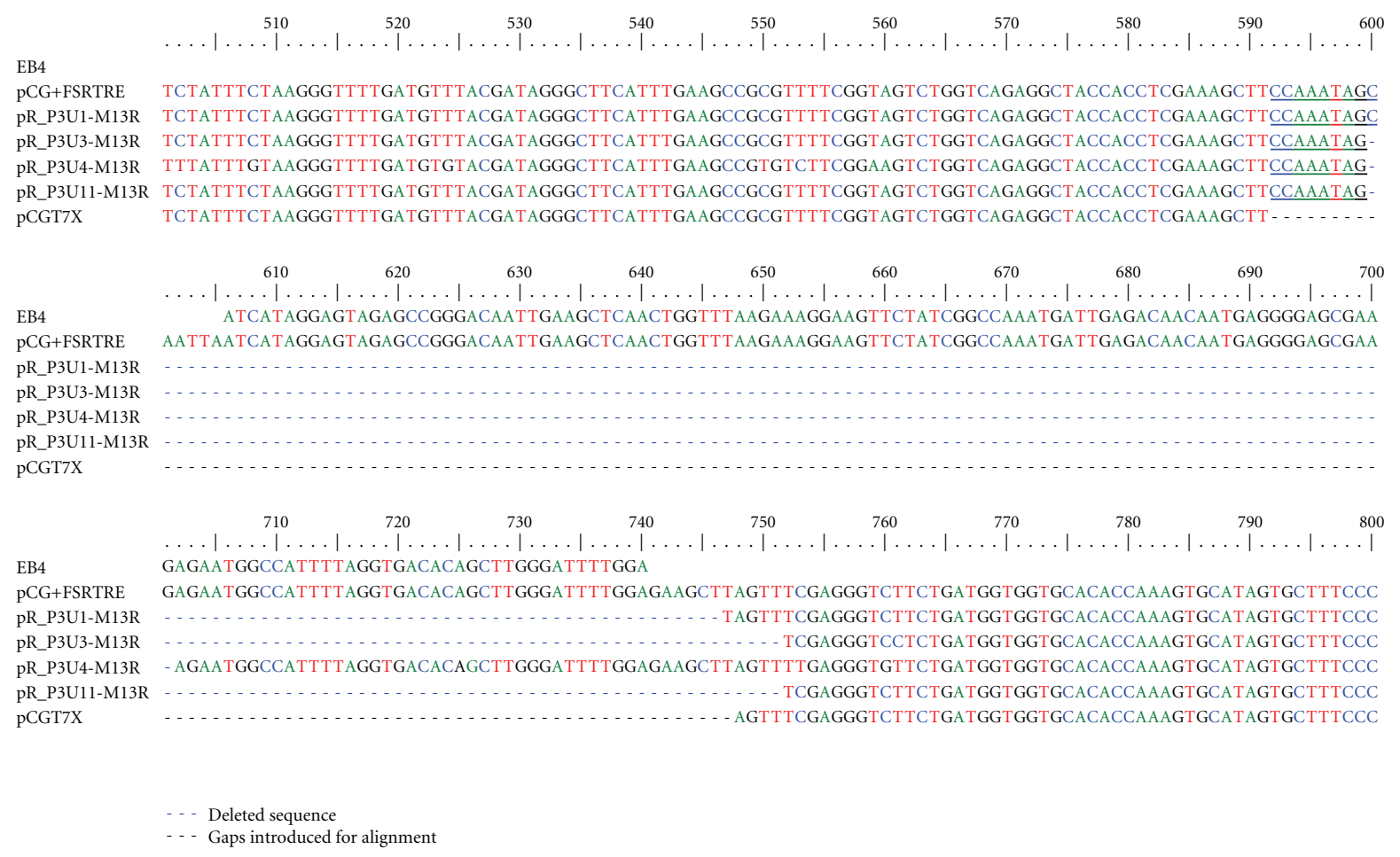

FIGURE 7: Sequence alignments of cloned RT-PCR-amplified products from putative chimeric CGMMV RNA at 30 dpi. Plasmid clones sent for sequence analysis were pR_P3U1, pR_P3U3, pR_P3U4, and pR_P3U11. The sequence alignment shows that EB4 sequence was not within the insert of plasmids, except for a partial sequence for pR_P3U4 clone. Only part of the downstream sequence of EB4 was detected together with $3^{\prime}$ untranslated region of CGMMV for pR_P3U4 clone, the rest were without EB4 sequence. Introduced read-through sequences and extra codons are underlined. Complete EB4 sequence is aligned accordingly with the other sequences.

TABLE 2: Amino acid sequence, isoelectric point (pI) and charge of wild type, constructed recombinant CGMMV coat protein (CP), and the EB4 insert.

\begin{tabular}{|c|c|c|c|c|}
\hline Clones & Amino acid sequence & $\begin{array}{c}\text { MW } \\
(\mathrm{kDa})\end{array}$ & $\mathrm{pI}$ of $\mathrm{CP}$ & $\begin{array}{c}\text { Charge } \\
\text { of CP }\end{array}$ \\
\hline EB4 & IIGVEPGQLKLNWFKKGSSIGQMIETTMRGAKRMAILGDT AWDFG & 5.0 & 9.53 & +1.9 \\
\hline & MAYNPITPSKLIAFSASYVPVRTLLNFLVASQGTAFQTQAGRD & \multirow{4}{*}{17.3} & \multirow{4}{*}{5.08} & \multirow{4}{*}{-3.1} \\
\hline Wild-type & SFRESLSALPSSVVDINSRFPDAGFYAFLNGPVLRPIFVSLLSST & & & \\
\hline CGMMV & DTRNRVIEVVDPSNPTTAESLNAVKRTDDASTAARAEIDNLIE & & & \\
\hline & SISKGFDVYDRASFEAAFSVVWSEATTSKA & & & \\
\hline \multirow{5}{*}{$\mathrm{pRT}^{*}$} & MAYNPITPSKLIAFSASYVPVRTLLNFLVASQGTAFQTQAGRD & \multirow{5}{*}{23.0} & \multirow{5}{*}{5.41} & \multirow{5}{*}{-2.1} \\
\hline & SFRESLSALPSSVVDINSRFPDAGFYAFLNGPVLRPIFVSLLSST & & & \\
\hline & DTRNRVIEVVDPSNPTTAESLNAVKRTDDASTAARAEIDNLIE & & & \\
\hline & SISKGFDVYDRASFEAAFSVVWSEATTSKACQQLIIGVEPGQ & & & \\
\hline & LKLNWFKKGSSIGQMIETTMRGAKRMAILGDTAWDFGEA & & & \\
\hline \multirow{5}{*}{$\mathrm{pRG}^{*}$} & MAYNPITPSKLIAFSASYVPVRTLLNFLVASQGTAFQTQAGRD & \multirow{5}{*}{23.1} & \multirow{5}{*}{5.69} & \multirow{5}{*}{-1.1} \\
\hline & SFRESLSALPSSVVDINSRFPDAGFYAFLNGPVLRPIFVSLLSST & & & \\
\hline & DTRNRVIEVVDPSNPTTAESLNAVKRTDDASTAARAEIDNLIE & & & \\
\hline & SISKGFDVYDRASFEAAFSVVWSEATTSKAWQQLIIGVEPGQ & & & \\
\hline & LKLNWFKKGSSIGQMIETTMRGAKRMAILGDTAWDFGQA & & & \\
\hline \multirow{5}{*}{ pCG+FSRTRE* } & MAYNPITPSKLIAFSASYVPVRTLLNFLVASQGTAFQTQAGRD & \multirow{5}{*}{22.9} & \multirow{5}{*}{5.41} & \multirow{5}{*}{-2.0} \\
\hline & SFRESLSALPSSVVDINSRFPDAGFYAFLNGPVLRPIFVSLLSST & & & \\
\hline & DTRNRVIEVVDPSNPTTAESLNAVKRTDDASTAARAEIDNLIE & & & \\
\hline & SISKGFDVYDRASFEAAFSVVWSEATTSKASGQLIIGVEPGQ & & & \\
\hline & LKLNWFKKGSSIGQMIETTMRGAKRMAILGDTAWDFGEA & & & \\
\hline
\end{tabular}

*With read-through leaky UAG amber stop codon. 
TABLE 3: Summary of sequence analyses carried out to confirm the presence of EB4 within the putative recombinant CGMMV. $\left({ }^{\#} \mathrm{~A}\right.$ truncated EB4 sequence was detected at 30 dpi according to Figure 7 for pR_P3U4 clone from nucleotide position 702 to 746 .)

\begin{tabular}{|c|c|c|c|}
\hline \multicolumn{4}{|c|}{ Presence of EB4 within putative chimeric CGMMV genome } \\
\hline \multirow{3}{*}{ Sample } & \multicolumn{3}{|c|}{ RNA source used for RT-PCR } \\
\hline & $\begin{array}{r}\text { Trans } \\
\text { pla }\end{array}$ & $\begin{array}{l}\text { t-inoculated } \\
\text { total RNA }\end{array}$ & $\begin{array}{c}\text { Virus particles } \\
\text { total RNA }\end{array}$ \\
\hline & $14 \mathrm{dpi}$ & $21 \mathrm{dpi}$ & $30 \mathrm{dpi}$ \\
\hline $\begin{array}{l}\text { Chimeric clone } \\
\text { (with pCG+FSRTRE } \\
\text { transcripts) }\end{array}$ & Present & $\begin{array}{c}\text { Present in } \\
<50 \% \text { of } \\
\text { plants tested }\end{array}$ & \#Not present \\
\hline
\end{tabular}

The positive results from the initial RT-PCR screening of transcript-inoculated plants at $14 \mathrm{dpi}$ (Figure 4) suggest the presence of EB4. The EB4 was, however, not detectable at $30 \mathrm{dpi}$, and only present in some $(<50 \%$ tested $)$ plants at $21 \mathrm{dpi}$. These findings strongly suggest that deletion had occurred within the host plants after $14 \mathrm{dpi}$. The sequence analyses in this section are summarized in Table 3.

\section{Discussion}

Plant virus vectors-based expression systems have been widely studied for their development as antigen presentation systems as well as for the production of pharmaceutically important peptides. The CGMMV has been previously shown to be suitable for expression of foreign peptide [7]. In this study, CGMMV vector was used to express a 45 amino acid EB4 gene. The integration of the EB4 gene into the end of CGMMV coat protein gene was done via a leaky UAG read-through sequence.

Transcripts generated from chimeric clones of pRT and pRG carrying CAA-UAG-CAA-UUA read-through codon sequences were not infectious. This is possibly caused by the failure of self assembly [16], and thus none of the inoculated plants was systemically infected. The assembly of CGMMV into virus particle has been shown to be essential for the viral movement through phloem [17], hence another chimeric clone pCG+FSRTRE was constructed carrying read-through sequence (AAA-UAG-CAA-UUA) from the wild-type CGMMV genome. The clone containing this read-through signal was infectious and produced chimeric CGMMV (Table 1 and Figures 4 and 5). It is, thus, postulated that there is a read-through signal preference between different species of tobamoviruses, in this case between TMV and CGMMV causing possibly viral particle assembly failure. It has also been shown that KGMMV, the tobamovirus, which has the closest genome similarity to CGMMV [13] also utilizes the same CGMMV read-through signal reaffirming the differences between the tobamoviruses. Additionally, unlike other plant virus vectors $[15,18]$, this study reaffirms that with CGMMV pI deviation did not appear to be a factor affecting infectivity [7].
The chimeric (carrying the EB4) and putative wild-type CGMMV were shown to coexist in the virus population of the infected plants (Figure 5). Previous reports show that the efficiencies of the leaky UAG codon varied from $0.5 \%$ to $5 \%$ so that the ratio of modified to unmodified CP would be between 1:200 and 1:20 [12, 19]. However, in this study, relatively high levels of chimeric coat protein was observed (Figure 5) giving a ratio of modified to unmodified CP of approximately $1: 1$. It has been suggested that muskmelon host plant could be producing higher levels of translation nonsense suppressor tRNA making the application of the translation read-through signal favorable in this host [7].

Due to their relatively higher rate of mutation during replication, RNA viruses are evolving rapidly and this is the basis of their ubiquity and adaptability $[20,21]$. In this study, it is shown that the EB4 gene sequence carried by the chimeric CGMMV was systemically removed during the infection process. The order of the removal of the transgene was speculated to be the $5^{\prime}$ to $3^{\prime}$ direction (Figures 6 and 7). This is further supported by the detection of two additional nucleotides together with the read-through sequence "CC-AAA-TAG" downstream from the CGMMV CP ORF. This report shows the temporal in-host truncation of the transgene from a chimeric virus in a natural host. Recent report has shown truncation occurring in transgenic plants expressing the same or similar transgenes as the chimeric virus [22] suggesting targeting by a resistance mechanism or competition with the parental virus as the mechanism involved. The exact mechanism of truncation of the transgene in our study is less clear as a previous study using the same vector and host with a different transgene did not exhibit the same instability [7]. The larger size of the EB4 peptide in comparison to the Hepatitis B epitope, however, suggests that the truncation mechanism or transgene recognition by the virus was size dependent.

In summary, we have shown that CGMMV has a readthrough codon preference and that the read-through codon for TMV was shown to be not efficient, as the chimeric CGMMV transcripts utilizing this signal were not infectious. The reported limitation of low-modified coat protein yield of this type of read-through transient expression system appears to have been overcome as relatively equal yield of chimeric and wild-type CGMMV coat protein were produced. This report also provides a rational harvesting timeline for the chimeric virus making this system exploitable for implementation in a plantation scale in the future. It can be suggested that once host plants are infected with the chimeric virus carrying the inserted foreign peptides, the optimum harvesting time would be at around 14 dpi or not more than 20 dpi in order to obtain maximum yield of the full-length transgene. Growth of the infected plants for longer periods to obtain higher yields of the chimeric virus may induce unwanted transgene deletions. This and other factors described earlier should be relevant information for the further development of CGMMV or other plant viruses as vectors for medically important peptides such as for dengue (this study) and Hepatitis B [7] viral antigens. 


\section{Acknowledgments}

The authors thank Ministry of Science, Technology and Innovation of Malaysia (Grant no. 36-02-03-6003) and the University of Malaya for financial support, and Dr. SiangHee Tan for the muskmelon seeds used in the study. A special thanks to Dr. Peter Palukaitis (SCRI) for his comments on the manuscript.

\section{References}

[1] J. M. Alamillo, W. Monger, I. Sola, et al., "Use of virus vectors for the expression in plants of active full-length and single chain anti-coronavirus antibodies," Biotechnology Journal, vol. 1, no. 10, pp. 1103-1111, 2006.

[2] Y. Gleba, V. Klimyuk, and S. Marillonnet, "Viral vectors for the expression of proteins in plants," Current Opinion in Biotechnology, vol. 18, no. 2, pp. 134-141, 2007.

[3] J. Johnson, T. Lin, and G. Lomonossoff, "Presentation of heterologous peptides on plant viruses: genetics, structure, and function," Annual Review of Phytopathology, vol. 35, pp. 67-86, 1997.

[4] C. Lacomme, L. Smolenska, and T. M. A. Wilson, "Genetic engineering and the expression and the expression of foreign peptides or proteins using plant virus-based vectors," in Genetic Engineering: Principles and Methods, J. K. Setlow, Ed., vol. 20, pp. 225-237, Plenum Press, New York, NY, USA, 1988.

[5] C. Porta and G. P. Lomonossoff, "Scope for using plant viruses to present epitopes from animal pathogens," Reviews in Medical Virology, vol. 8, no. 1, pp. 25-41, 1998.

[6] K. Dalsgaard, A.. Uttenthal, T. D. Jones, et al., "Plant-derived vaccine protects target animals against a viral disease," Nature Biotechnology, vol. 15, no. 3, pp. 248-252, 1997.

[7] A. Ooi, S. Tan, R. Mohamed, N. Abdul Rahman, and R. Y. Othman, "The full-length clone of cucumber green mottle mosaic virus and its application as an expression system for Hepatitis B surface antigen," Journal of Biotechnology, vol. 121, no. 4, pp. 471-481, 2006.

[8] A. A. Brunt, K. Crabtree, M. J. Dallwitz, A. J. Gibbs, L. Watson, and E. J. Zurcher, "Cucumber green mottle mosaic tobamovirus," Plant Viruses Online: Descriptions and Lists from the VIDE Database, 1996, http://image.fs.uidaho.edu/ vide/descr265.htm.

[9] M. Ugaki, M. Tomiyama, T. Kakutani, et al., "The complete nucleotide sequence of cucumber green mottle mosaic virus (SH strain) genomic RNA," Journal of General Virology, vol. 72, no. 7, pp. 1487-1495, 1991.

[10] L. van Vloten-Doting, J.-F. Bol, and B. Cornelissen, "Plantvirus-based vectors for gene transfer will be of limited use because of the high error frequency during viral RNA synthesis," Plant Molecular Biology, vol. 4, no. 5, pp. 323-326, 1985.

[11] H. Wang and G. Stubbs, "Structure determination of cucumber green mottle mosaic virus by X-ray fiber diffraction. Significance for the evolution of tobamoviruses," Journal of Molecular Biology, vol. 239, no. 3, pp. 371-384, 1994.

[12] J. M. Skuzeski, L. M. Nichols, R. F. Gesteland, and J. F. Atkins, "The signal for a leaky UAG stop codon in several plant viruses includes the two downstream codons," Journal of Molecular Biology, vol. 218, no. 2, pp. 365-373, 1991.

[13] S.-H. Tan, M. Nishiguchi, M. Murata, and F. Motoyoshi, "The genome structure of kyuri green mottle mosaic tobamovirus and its comparison with that of cucumber green mottle mosaic tobamovirus," Archives of Virology, vol. 145, no. 6, pp. 1067-1079, 2000.

[14] Y. Sugiyama, H. Hamamoto, S. Takemoto, Y. Watanabe, and Y. Okada, "Systemic production of foreign peptides on the particle surface of tobacco mosaic virus," FEBS Letters, vol. 359, no. 2-3, pp. 247-250, 1995.

[15] M. Bendahmane, M. Koo, E. Karrer, and R. N. Beachy, "Display of epitopes on the surface of tobacco mosaic virus: impact of charge and isoelectric point of the epitope on virushost interactions," Journal of Molecular Biology, vol. 290, no. 1, pp. 9-20, 1999.

[16] V. Yusibov, A. Modelska, K. Steplewski, et al., "Antigens produced in plants by infection with chimeric plant viruses immunize against rabies virus and HIV-1," Proceedings of the National Academy of Sciences of the United States of America, vol. 94, no. 11, pp. 5784-5788, 1997.

[17] L. Simón-Buela and F. García-Arenal, "Virus particles of cucumber green mottle mosaic tobamovirus move systemically in the phloem of infected cucumber plants," Molecular Plant-Microbe Interactions, vol. 12, no. 2, pp. 112-118, 1999.

[18] K. Uhde-Holzem, R. Fischer, and U. Commandeur, "Genetic stability of recombinant potato virus $\mathrm{X}$ virus vectors presenting foreign epitopes," Archives of Virology, vol. 152, no. 4, pp. 805-811, 2007.

[19] H. R. B. Pelham, "Translation of tobacco rattle virus RNAs in vitro: four proteins from three RNAs," Virology, vol. 97, no. 2, pp. 256-265, 1979.

[20] E. D. Kilbourne, "New viruses and new disease: mutation, evolution and ecology," Current Opinion in Immunology, vol. 3, no. 4, pp. 518-524, 1991.

[21] E. Domingo and J. J. Holland, "RNA virus mutations and fitness for survival," Annual Review of Microbiology, vol. 51, pp. 151-178, 1997.

[22] B.-N. Chung, T. Canto, and P. Palukaitis, "Stability of recombinant plant viruses containing genes of unrelated plant viruses," Journal of General Virology, vol. 88, no. 4, pp. 1347-1355, 2007. 

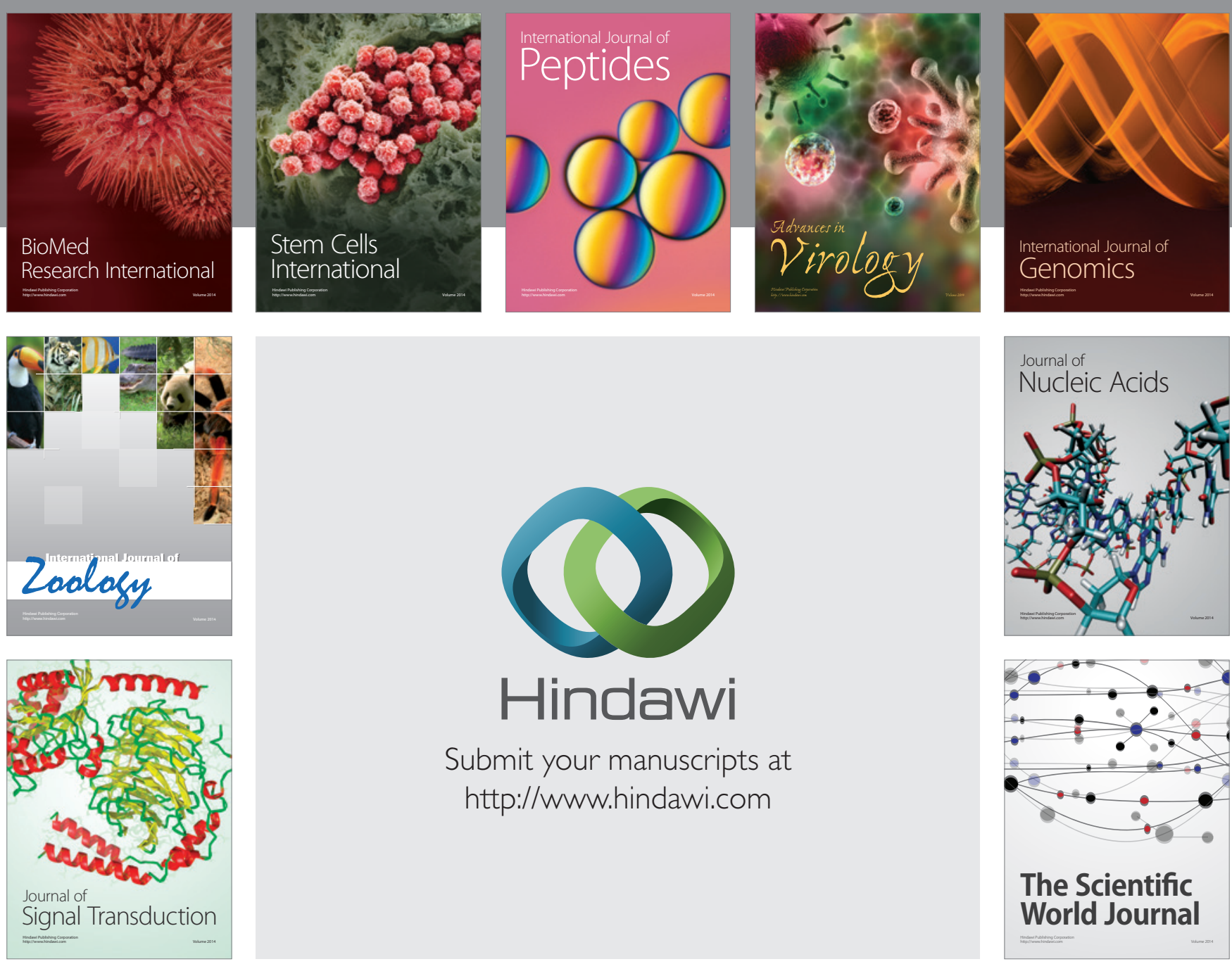

Submit your manuscripts at

http://www.hindawi.com
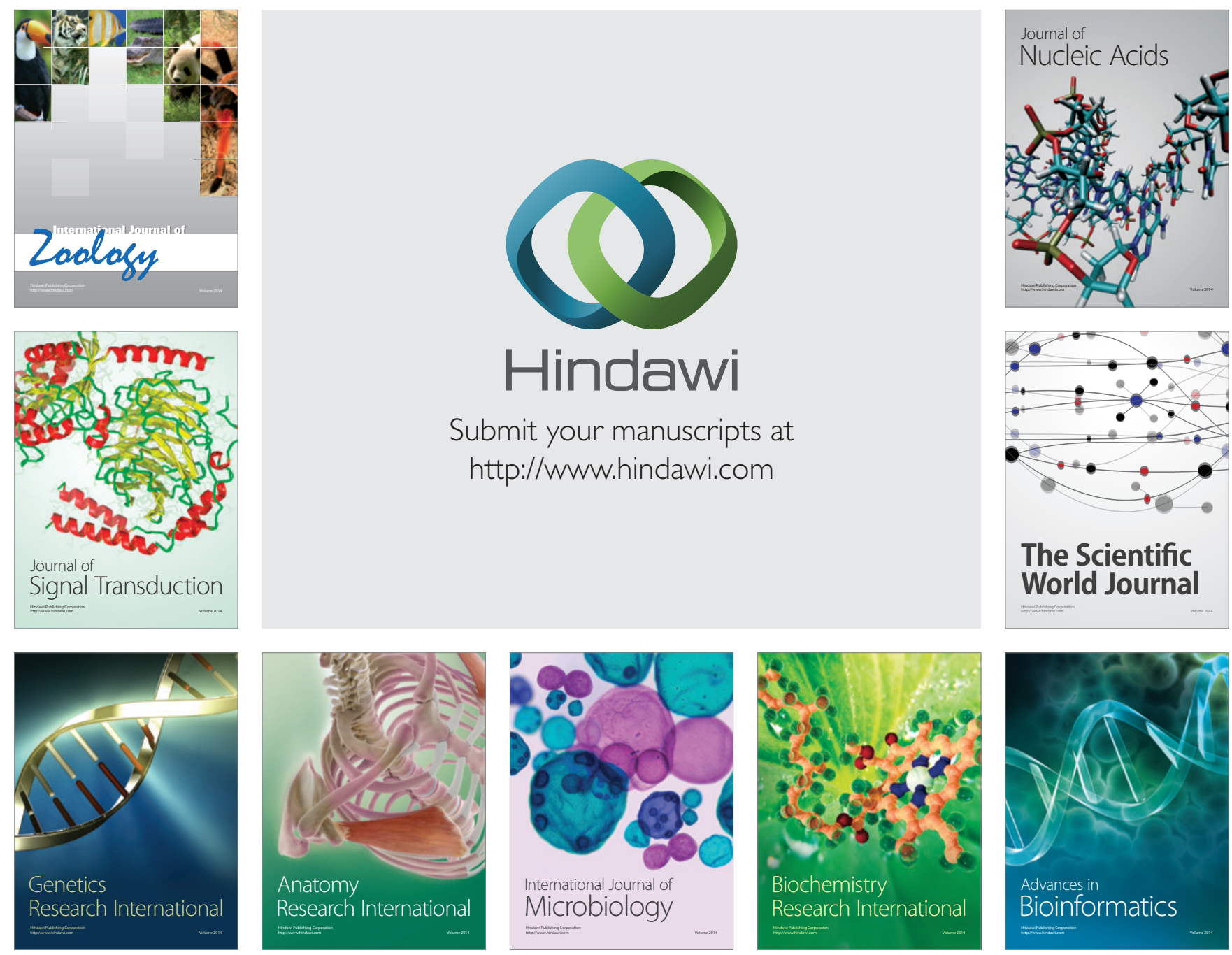

The Scientific World Journal
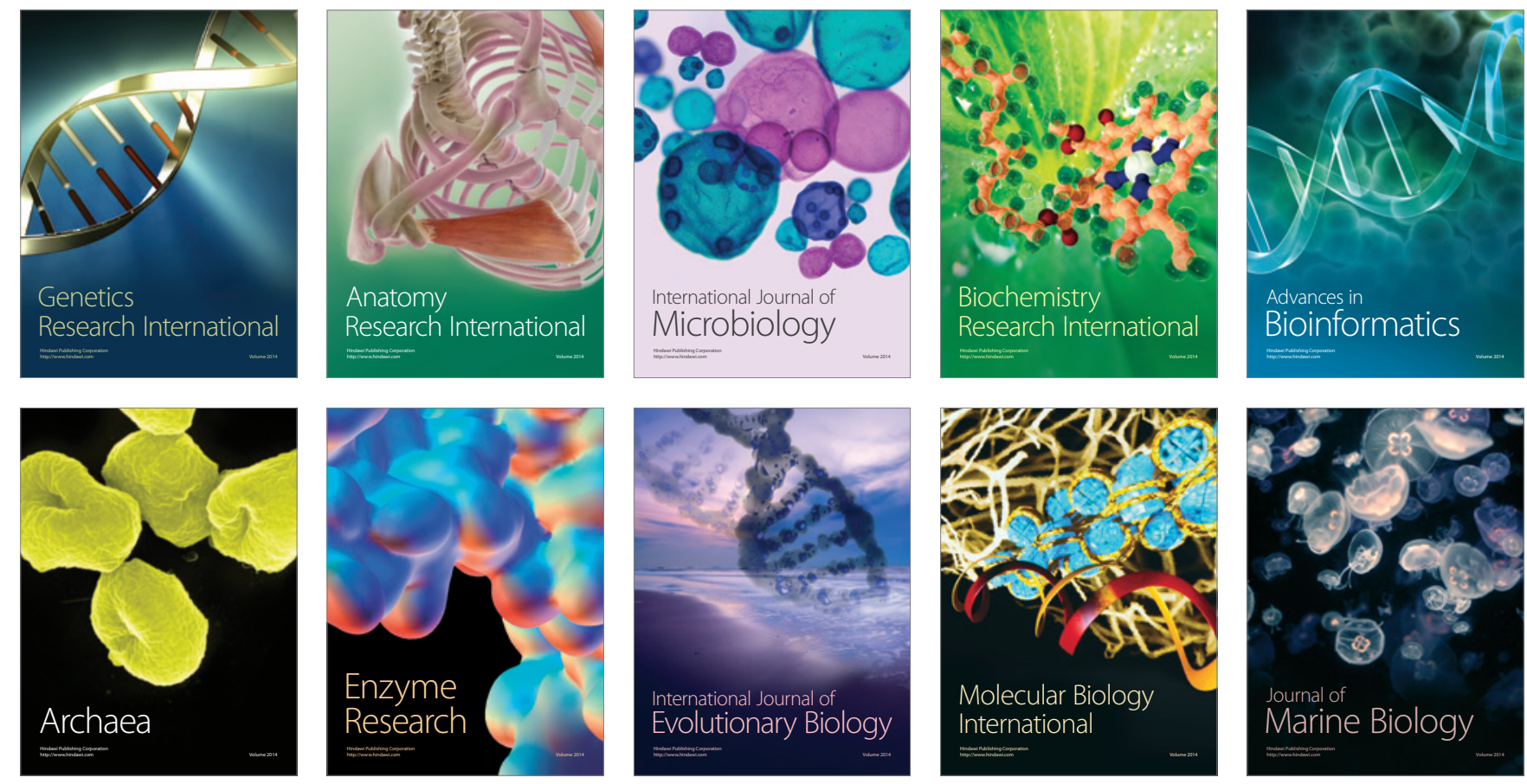